\title{
BUILDING INSURANCE BRAND IMAGE IN THE SME SECTOR IN POLAND - AN EMPIRICAL STUDY
}

\author{
Aneta ONISZCZUK-JASTRZABEK $K^{1}$ \\ Joanna $B E D N A R Z^{2}$ \\ Tomasz $C Z U B A^{3}$ \\ Piotr Oskar CZECHOWSKI ${ }^{4}$
}

\begin{abstract}
The source of the distinctive offer are: product design, its features, technology of production, consumer services and a well-known brand appreciated by consumers. Branded products are perceived by consumers as remarkable, that are not able to be substituted by the goods offered by competitors. The brand and its image provide the customer with an emotional or symbolic benefits that are essential in building strong relations between a company and its clients. The similar mechanism is observed on the insurance market. PZU SA has been the best known Polish insurance company indicated by SMEs for the period 2012-2017. It is worth to mention that its spontaneous brand awareness is over 90\%. For these reasons PZU SA can be perceived as a good example of the business model for other insurance companies. The aim of this paper is to identify the most important factors that affect the image of insurance companies present on the Polish market. Basing on the association tests the authors also tried to discover the specific image of each company. The method of direct interview was used to collect data from respondents representing the SME sector (survey method: direct interview (PAPI)). For each of the groups, the sampled group is representative. To present results independently from the number of employees shown in the report as SMEs IN TOTAL (weighted data in total), a system of weightings was developed to allow obtaining results for the entire market. The sampling was done randomly using a list of companies drawn up by the Main Statistical Office (GUS). The algorithm for selecting companies to represent the SME sector was developed by a specialist from Qualifact company. Companies were chosen with the use of systematic draw technique. Targeting the examined population according to the section (production, construction, trade, hotels / restaurants, transport, financial intermediation, real estate, education, others) and province, guaranteed appropriate proportion of the number of companies representing different economic sectors.
\end{abstract}

Key words: brand, insurance, SME, Poland

JEL code: G20, G22, M21, M31

\section{Introduction}

Product brand or corporate brand has become a powerful marketing tool in the 20th century.

Creating a strong brand should be a fundamental process in every company. A well-known brand is a symbol of company's image and a special value that permits to improve current market position as well as to undertake challenges of its expansion abroad. Due to the wide variety of products offered on the market, consumers progressively are guided not only by the quality or benefits they deliver, but also by the reputation of the business entity. Empiricism in marketing shows that the better the company's reputation is, the more customers are ready to purchase goods offered by this firm. The

\footnotetext{
${ }^{1}$ Associated Prof. PhD., Gdańsk University, Poland, e-mail: ekoao@ug.edu.pl

${ }^{2}$ Associated Prof. PhD. , Gdańsk University, Poland, e-mail: j.bednarz@ug.edu.pl

${ }^{3}$ Assistant Prof. PhD., Gdańsk University, Poland, e-mail: t.czuba@ug.edu.pl

${ }^{4}$ Associated Prof. PhD., Gdynia Maritime University, Poland, oskar.czechowski@ibs24.eu
}

DOI: 10.29302/oeconomica.2018.20.1.2 
positive image of the company contributes to the increasing level of customers' loyalty, simplifying the decision making process and confirming the right choice they have made.

On the Polish insurance market there is one leader - the company PZU SA. This company is the best known Polish insurer indicated by SMEs for the period 2012-2017. Its spontaneous brand awareness is over $90 \%$. For these reasons PZU SA can be perceived as a good example of the business model for other insurance companies.

The aim of this paper is to identify the most important factors affecting the image of insurance companies present on the Polish market. Basing on the association tests the authors also tried to discover the specific image of each company.

\section{Brand notion and function}

In the literature, there is no widely adopted brand definition [Cohen, 2017]. This follows from the fact that experts dealing with branding look at this issue from various points of view and associate it with different elements. The definition which is known best is the one elaborated by the American Marketing Association - a leading organisation in the field of marketing, enjoying a considerable confidence with professionals and scientists. Brand is a name, term, symbol, design or any other element which is to identify and differentiate goods or services of one supplier from goods of other, competing suppliers. A brand often makes reference to symbols such as: a name, a logotype, a marketing slogan, a and designing system [American Marketing Association, 2017].

Many other authors perceive brand in a similar way, stressing its elements. J. Kall, names the brand as: "(..) a combination of physical product, brand name, packaging, and advertising as well as activities in the scope of distribution and price accompanying those elements - a combination which by differentiating a manufacturer's offer from competitors' offers provides consumers with distinguishing functional and/or symbolic advantages - establishing in this way a loyal group of purchasers and at the same time enabling reaching the leading market position" [Kall, 2006].

Similarly, P. Kotler defines brand as a goods or service whose features differentiate them in some way from goods or services which were produced to satisfy the same needs [Kotler, 2012, p. 263-264]. First of all, a brand is a set of features of the product and of advantages received by the customer buying the specified goods. The essence of a brand is the position which it takes is consumers' awareness [Staszyńska, 2013]. Therefore, through the brand, the consumers identify the manufacturer or the seller.

Often, a brand is also identified as a specified product/service. According to "Słownik języka polskiego" (Polish Language Dictionary), brand is a factory or company mark placed on a company products, which defines the manufacturer, indicates products quality, protects them against reproduction or counterfeiting [Szymczak, 1981].

Yet, a brand is not a symbol but a certain type of declaration, a promise. Just such promise should shape the whole comportment and acting strategy of a company. It is placed in the centre of a business entity marketing communication. Brand creation is a basic marketing task for an enterprise as a strong brand supports building the competitiveness of the company on the market, and to a considerable extent, it functions both, as an indicator of a company value and a very powerful competition tool [Dębski, 2009].

The key element of brand management is a product, service, or enterprise name. Brand name is an omnipresent mark identifying a product, and it distinguishes the product from other products or manufacturers. Apart from colour, logotype, drawing, or symbol, it is the key component of brand identity, sometimes named: "external brand". The name creates also the brand image, since the name indicates the product, designs its image, evaluates it, adds emotions, suggests or even imposes the interpretation of a brand image. This is so because the name - as a language communiqué - brings individual semantic, associative, and connotative contents. They are then 
received by the consumer and subconsciously projected from the name to the very brand - in the form of meanings, associations, images, conceptions, or impressions which altogether shape the complex, psychological image of the brand. Besides, the marketing name initiates best and then, in the best way strengthens (maintains) the brand awareness [Bednarz, 2015; Bednarz, 2007].

Image creation and building brand awareness is called "brand positioning" and it consists in building a brand meaning based on the following aspects: features of product associating, advantages, values, culture, personality of brand owner, and customer type [Kotler, 2012].

The basic functions of the brand are [Pilarczyk, Mruk, 2006]:

- differentiating function which allows differentiating a goods among other competitive goods,

- identifying function related to specific product properties, showing advantages following form possessing the product; it defines the purchasers segment, suggests the type of the user,

- promotion function is the way of communication of the enterprise with potential customers,

- warranty function which obliges the brand owner to maintain product quality on a determined level.

According to consumers' impressions, brands are divided into strong and weak ones, and the strength is decided by the type of associations related to a specific brand. Associations related to brands are divided into those related to a specific category of products which the brand belongs to, and those related to the enterprise image. In the process of goods purchasing, the brand awareness, meant as the ability to recognise the brand by a potential customer, or the awareness that a specified brand belongs to a specified group of products, are very important [Kall, Kłeczek, Sagan, 2013].

\section{Brand equity and value}

In one of the publications, P. Kotler presented the following definition of brand value: "Brand value is determined on the basis of customers' loyalty, name awareness perceived as product quality, strength of customers' associations, and other assets such as patents, trademarks and relations with distribution channel members" [Kotler, 2001]. Brands vary among themselves by value and strength. On the market, there are brands both, perfectly well known by the majority of consumers as well as those completely unknown. Strong brands are defined as possessing the brand value (equity); the higher the level of the brand equity building factors, the higher the brand equity is.

It is assumed that there are three approaches to brand equity. These are [Urbanek, 2002]:

1. Financial approach where the brand equity is perceived as the money value and it is defined depending on the measurement method. The equity is defined as:

- brand replacement cost,

- current proceeds from the brand, taking into account the risk and profits related to the brand,

- current value of future proceeds from branding products with a brand, and the in plus difference between the value of future cash flows related to products branded with the specified brand and the value of cash flows referring to similar unbranded products.

2. Marketing approach where the brand equity is defined as:

- a set of associations and behaviour of the brand consumers, members of distribution channels and enterprise employees, which cause that the brand generates higher proceeds in comparison with products not marked with the brand logo,

- extra advantage related to brand equity, but not related to features of a specific product, 
- factor which triggers various reactions of brand consumers towards marketing activities, i.e. different consumers' reactions to the same marketing-mix elements of branded products and unbranded products.

Broadened approach where the brand equity is a residual value and shows how various types of marketing activities affect persons who were subjected to such activities in order to define how the activities influence their impressions and attitude towards the brand.

\section{Brand in insurance company - results of market research}

\section{Method of research}

The method of direct interview was used to collect data from respondents representing the SME sector. For each of the groups, the sampled group is representative. To present results independently from the number of employees shown in the report as SMEs in total (weighted data in total), a system of weightings was developed to allow obtaining results for the entire market. The interviews were hold in the following periods: 9.03.2012-30.03.2012; 12.04.2013-12.05.2013; 20.03.2014-11.04.2014; 5.03.2015 - 26.03.2015; 19.06.2017 - 10.07. 2017.

The research was carried out in all of the 16 provinces in Poland.

Table 1.

Size of sample

\begin{tabular}{|l|l|l|l|l|}
\hline Year & $\begin{array}{l}\text { Total } \\
\text { SME }\end{array}$ & $\begin{array}{l}\text { Micro } \\
(0-9 \text { employees })\end{array}$ & $\begin{array}{l}\text { Small } \\
(10-49 \text { employees })\end{array}$ & $\begin{array}{l}\text { Medium } \\
(50-249 \text { employees })\end{array}$ \\
\hline 2012 & 1094 & $\mathrm{n}=612$ & $\mathrm{n}=318$ & $\mathrm{n}=164$ \\
\hline 2013 & 1094 & $\mathrm{n}=603$ & $\mathrm{n}=300$ & $\mathrm{n}=200$ \\
\hline 2014 & 1100 & $\mathrm{n}=600$ & $\mathrm{n}=300$ & $\mathrm{n}=200$ \\
\hline 2015 & 1100 & $\mathrm{n}=600$ & $\mathrm{n}=300$ & $\mathrm{n}=200$ \\
\hline 2017 & 1100 & $\mathrm{n}=600$ & $\mathrm{n}=300$ & $\mathrm{n}=200$ \\
\hline
\end{tabular}

Source: Qualifact. Market research and analysis, Report: Finanse MSP 2012. Rynek ustug ubezpieczeniowych, Gdańsk 2012, p. 7; Qualifact. Market research and analysis, Report: Finanse MSP 2013. Rynek ustug ubezpieczeniowych, Gdańsk 2013, p. 7; Qualifact. Market research and analysis, Report: Finanse MSP 2014. Rynek ustug ubezpieczeniowych, Gdańsk 2014, p. 7; Qualifact. Market research and analysis, Report: Finanse MSP 2015. Rynek ustug ubezpieczeniowych, Gdańsk 2015, p. 7; Own research in 2017.

The samples (Table 1) were collected randomly from a list of companies prepared by the Polish Statistical Office [GUS]. The sampling algorithm for choosing companies representing the SME sector was developed by a team of specialists from Qualifact Company.

The companies were selected through systematic sampling. Thanks to the layering of the population under research by section (manufacturing, construction, commerce, hotels / restaurants, transport, financial services, real estate agencies, education, other, etc.) and province, it was possible to select representatives of various sectors of the economy in the right proportions.

\section{Spontaneous brand awareness}

PZU SA is the most widely known insurance company among the enterprises. Spontaneous brand awareness of PZU SA has been declared by over 92\% of SME in 2012-2017 period. It is important that the spontaneous brand awareness of PZU SA declares from year to year more and more SME. In 2012 it was 92,7\%, in 2013 94,4\%, in 2014 93,7\%, in $201595,3 \%$ and in 2017

96,1\%. (Fig. no. 1). Other places (2017) are taken by: Warta (56,5\%), Ergo Hestia (32,3\%), Axa $(30,2 \%)$ and Allianz (26,3\%). The highest rating of TOM (Top of Mind) belongs also to PZU SA $(48,2 \%)$. Second is Warta (10.2\%), third Allianz (9.6\%). 


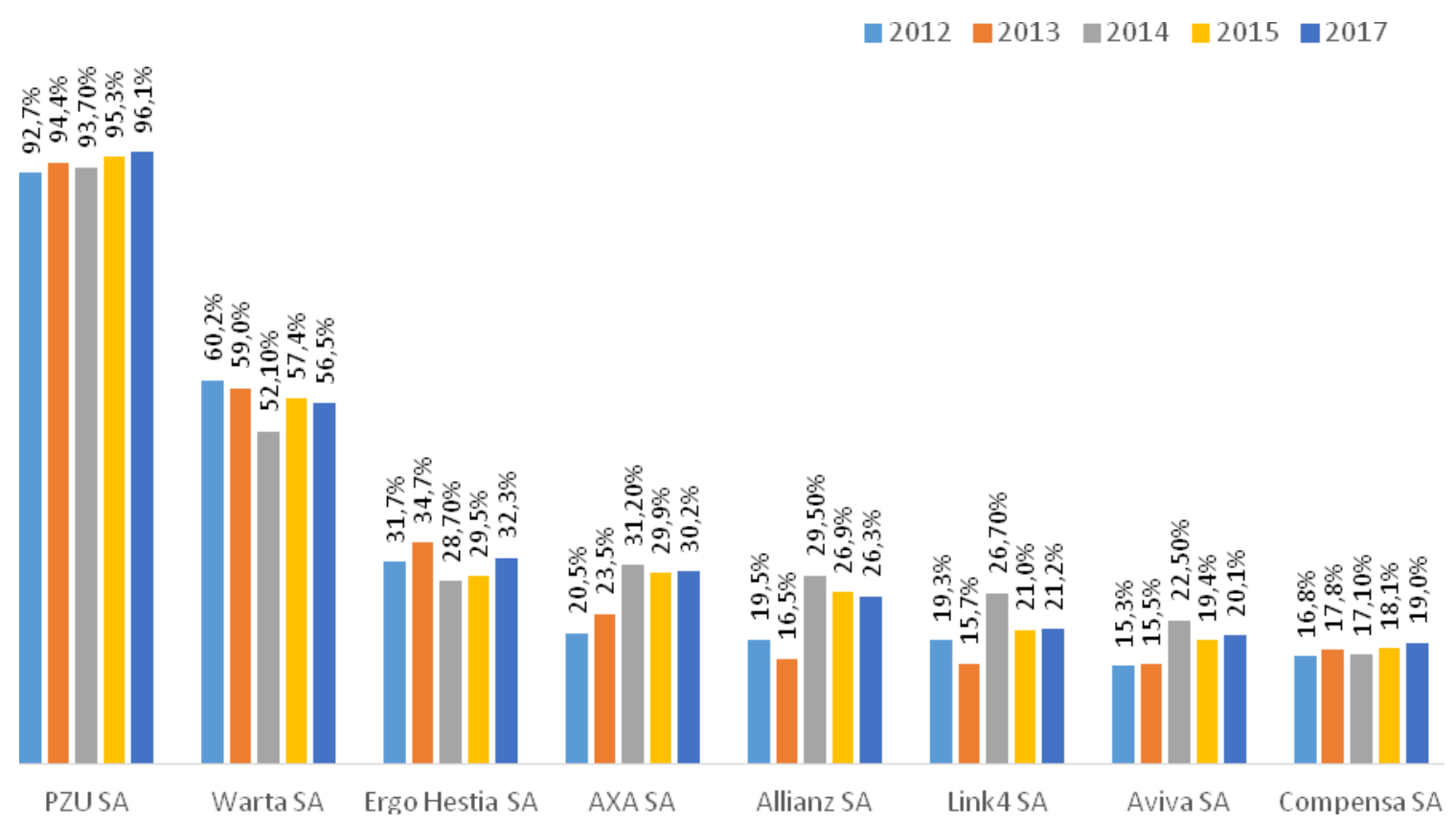

Fig. 1. Spontaneous brand awareness of insurance companies' names among SME in 20122015, 2017 [TOP 8]

Source: Qualifact. Badania rynkowe i doradztwo, Raport: Finanse MSP 2012. Rynek ustug ubezpieczeniowych, Gdańsk 2012, s. 144; Qualifact. Badania rynkowe i doradztwo, Raport: Finanse MSP 2013. Rynek ustug ubezpieczeniowych, Gdańsk 2013, s. 152; Qualifact. Badania rynkowe i doradztwo, Raport: Finanse MSP 2014. Rynek usług ubezpieczeniowych, Gdańsk 2014, s. 165; Qualifact. Badania rynkowe i doradztwo, Raport: Finanse MSP 2015. Rynek usług ubezpieczeniowych, Gdańsk 2015, s. 148; Own research in 2017.

\section{Image of insurance companies}

Profile analysis method was applied to analyze the image of insurance companies. Customers of insurance companies assessed 7 elements of the image (reliability, understanding of enterprise's needs, modernity, dynamism, professionalism, range of offer and prestige of insurer), indicating their marks on a 5-point semantic scale.

In 2012 (Fig. no. 2 and 3) in the case of micro (evaluated by at least 11 companies) and medium companies (evaluated by at least 11 companies) the highest rate of synthetic image ${ }^{5}$ obtained Compensa SA (32,71 points) and Aviva SA (34,18 points), for medium enterprises (evaluated by at least 9 companies) Ergo Hestia SA (33,89 points). The highest rate, regardless of size of respondents, was granted for the reliability and professionalism (Fig. no. 4 and 5).

In 2013 in the case of micro and medium companies PZU SA achieved the highest rate of synthetic image (32,19 points in micro- and 32,12 points in medium size companies), for medium enterprises Ergo Hestia SA (33,38 points).

Among SME companies in 2017, PZU SA obtained the highest rate of synthetic image (31,35 points).

Among elements of the image taken into account in the empirical study, in each of the seven assessed aspects, the leader is PZU SA (Fig. 4-10). The next places belong to the companies Warta SA and Ergo Hestia SA. It is worth noting that the highest ratings are obtained by the leaders of the insurance market in Poland and at the same time by insurers whose spontaneous awareness factor is the highest (compare Fig. no. 1).

\footnotetext{
${ }^{5}$ Synthetic image indicator - is the sum of assessed seven image items and its maximum value is 35 points.
} 


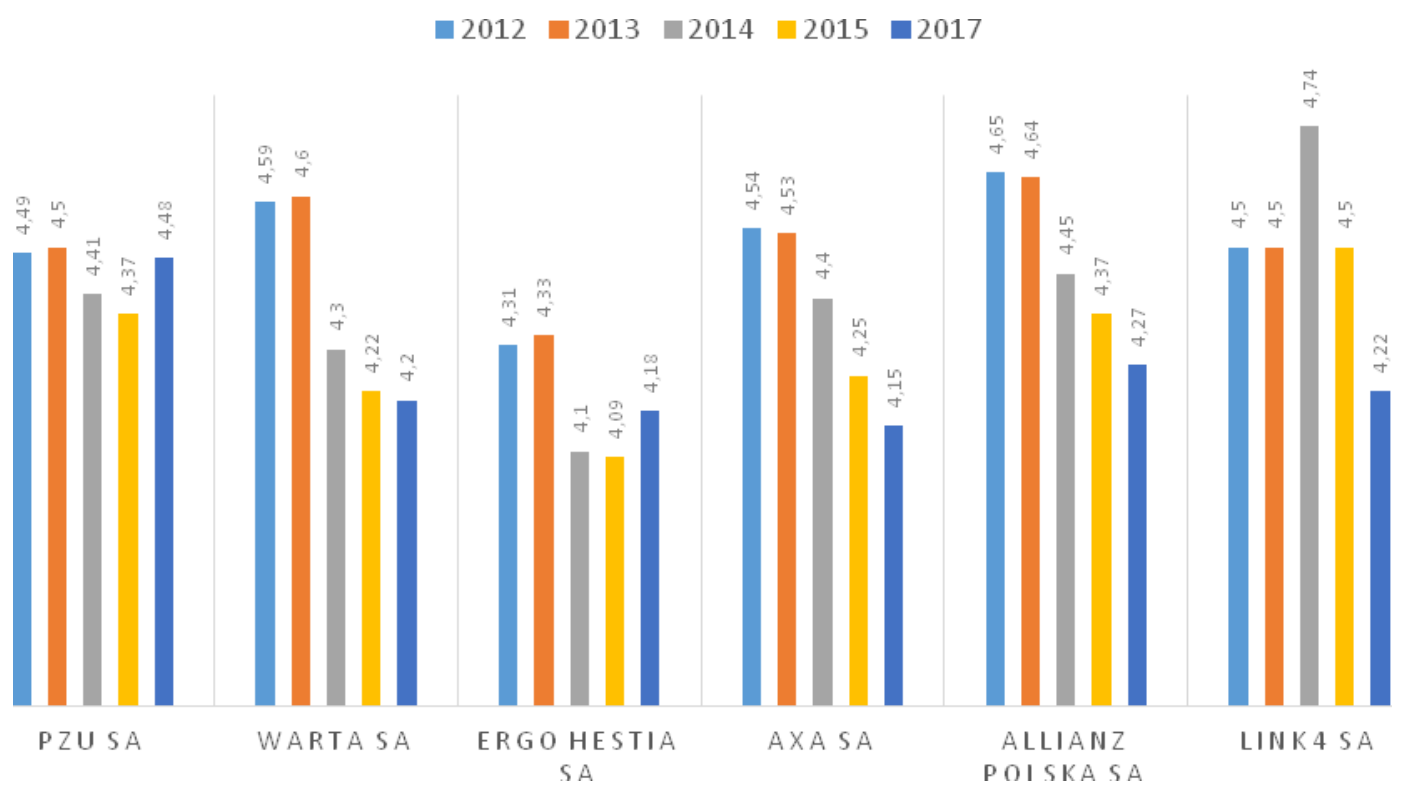

Fig. 2. Overall assessment for insurer [TOP 6]

Source: Qualifact. Badania rynkowe i doradztwo, Raport: Finanse MSP 2012. Rynek usług ubezpieczeniowych, Gdańsk 2012, s. 147; Qualifact. Badania rynkowe i doradztwo, Raport: Finanse MSP 2013. Rynek ustug ubezpieczeniowych, Gdańsk 2013, s. 154; Qualifact. Badania rynkowe i doradztwo, Raport: Finanse MSP 2014. Rynek usług ubezpieczeniowych, Gdańsk 2014, s. 167; Qualifact. Badania rynkowe i doradztwo, Raport: Finanse MSP 2015. Rynek usług ubezpieczeniowych, Gdańsk 2015, s. 151; Own research in 2017.

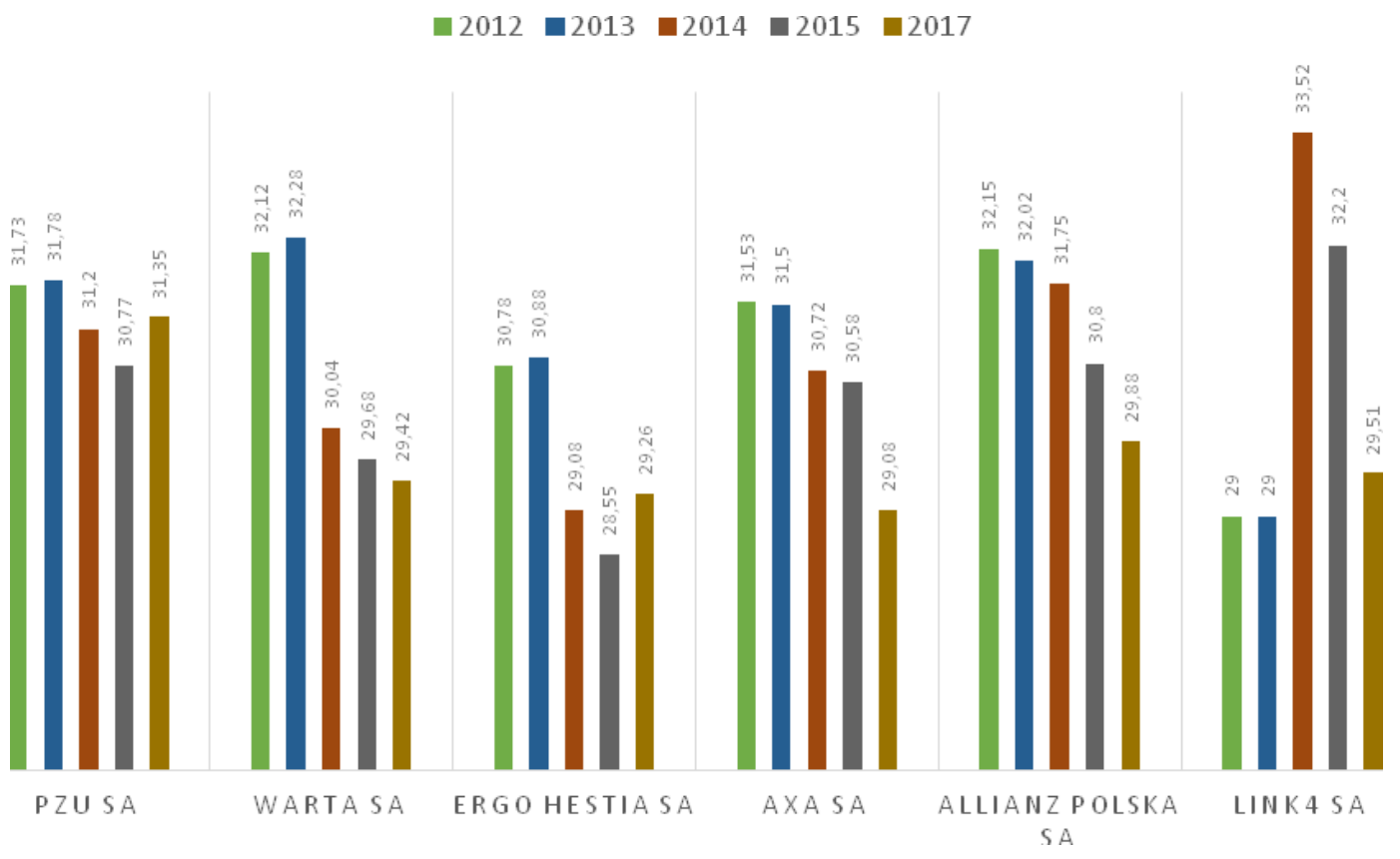

Fig. 3. Synthetic indicator for image of insurers [TOP 6]

Source: Qualifact. Badania rynkowe i doradztwo, Raport: Finanse MSP 2012. Rynek ustug ubezpieczeniowych, Gdańsk 2012, s. 147; Qualifact. Badania rynkowe i doradztwo, Raport: Finanse MSP 2013. Rynek ustug ubezpieczeniowych, Gdańsk 2013, s. 154; Qualifact. Badania rynkowe i doradztwo, Raport: Finanse MSP 2014. Rynek usług ubezpieczeniowych, Gdańsk 2014, s. 167; Qualifact. Badania rynkowe i doradztwo, Raport: Finanse MSP 2015. Rynek usług ubezpieczeniowych, Gdańsk 2015, s. 151; Own research in 2017. 


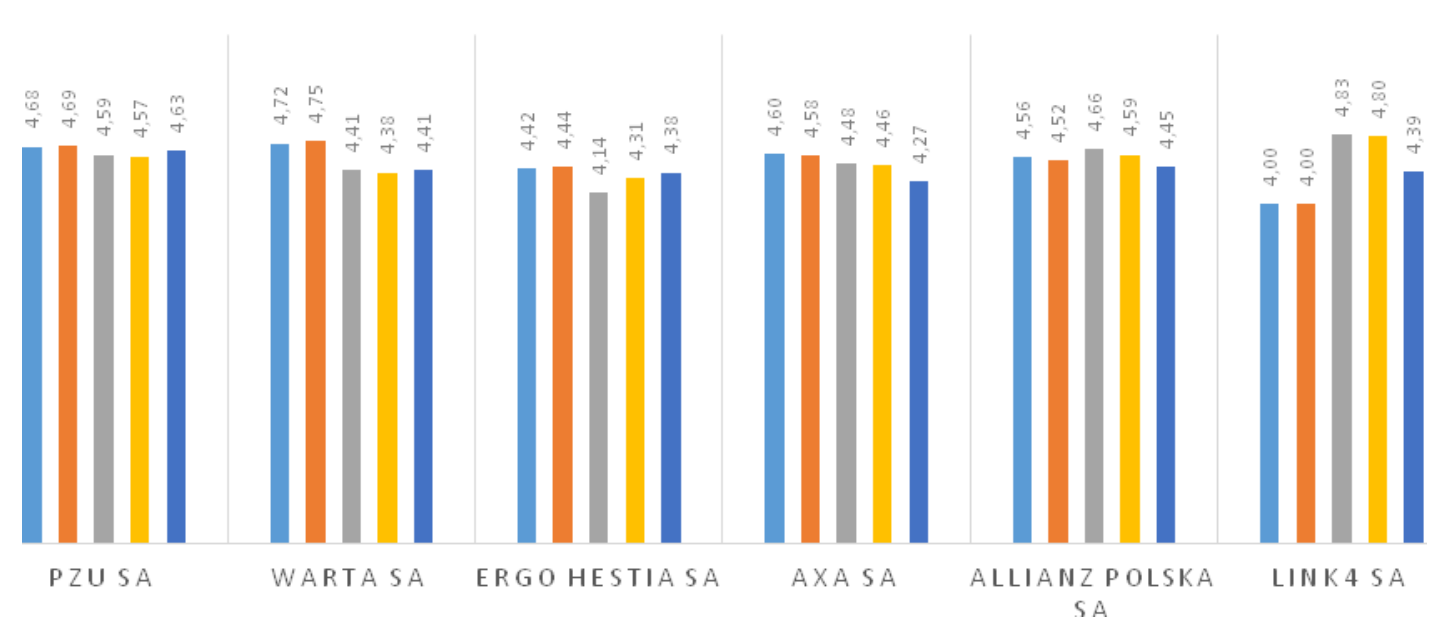

Fig. 4. Detailed indicators for image of insurance companies - reliability [TOP 8]

Source: Qualifact. Badania rynkowe i doradztwo, Raport: Finanse MSP 2012. Rynek ustug ubezpieczeniowych, Gdańsk 2012, s. 148; Qualifact. Badania rynkowe i doradztwo, Raport: Finanse MSP 2013. Rynek ushg ubezpieczeniowych, Gdańsk 2013, s. 155; Qualifact. Badania rynkowe i doradztwo, Raport: Finanse MSP 2014. Rynek usług ubezpieczeniowych, Gdańsk 2014, s. 168; Qualifact. Badania rynkowe i doradztwo, Raport: Finanse MSP 2015. Rynek usług ubezpieczeniowych, Gdańsk 2015, s. 153; Own research in 2017.

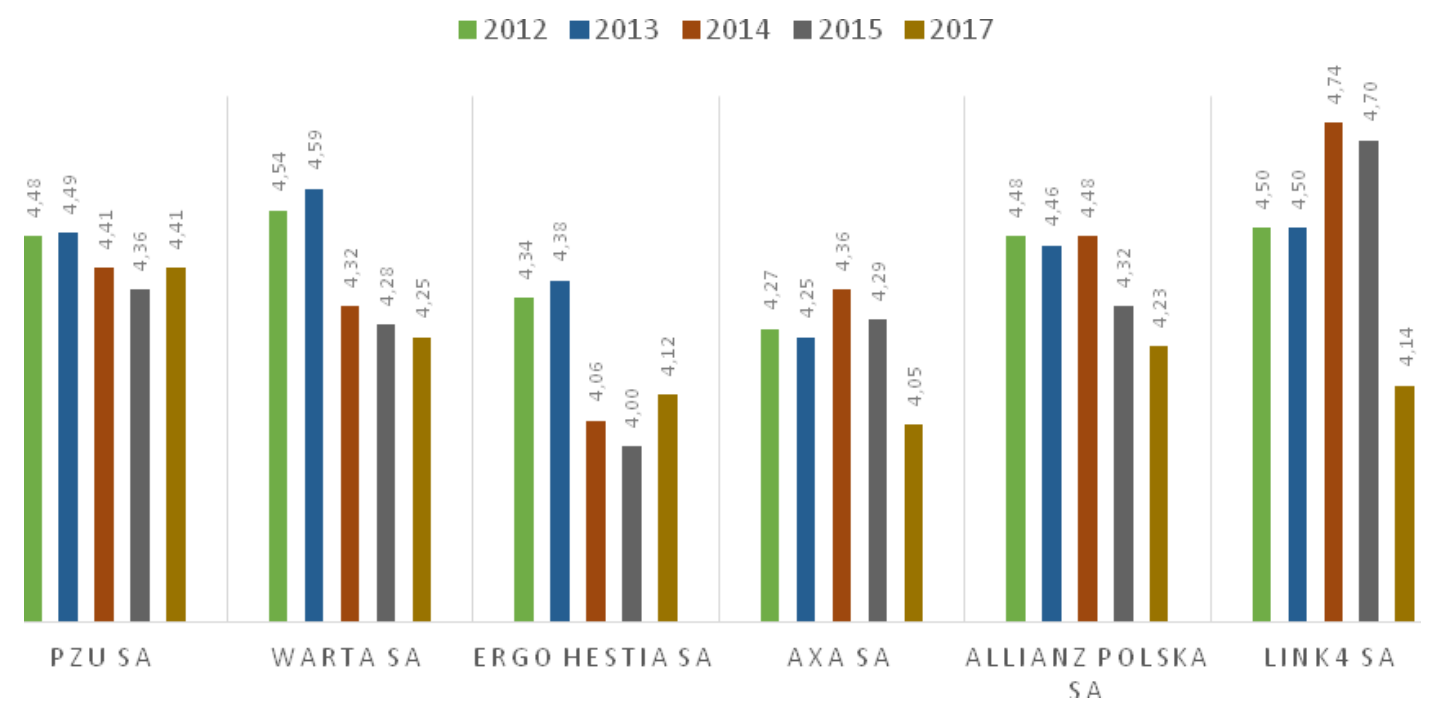

Fig. 5. Detailed indicators for image of insurance companies - understanding of enterprise's needs [TOP 8]

Source: Qualifact. Badania rynkowe i doradztwo, Raport: Finanse MSP 2012. Rynek ustug ubezpieczeniowych, Gdańsk 2012, s. 148; Qualifact. Badania rynkowe i doradztwo, Raport: Finanse MSP 2013. Rynek ustug ubezpieczeniowych, Gdańsk 2013, s. 155; Qualifact. Badania rynkowe i doradztwo, Raport: Finanse MSP 2014. Rynek usług ubezpieczeniowych, Gdańsk 2014, s. 168; Qualifact. Badania rynkowe i doradztwo, Raport: Finanse MSP 2015. Rynek usług ubezpieczeniowych, Gdańsk 2015, s. 153; Own research in 2017. 


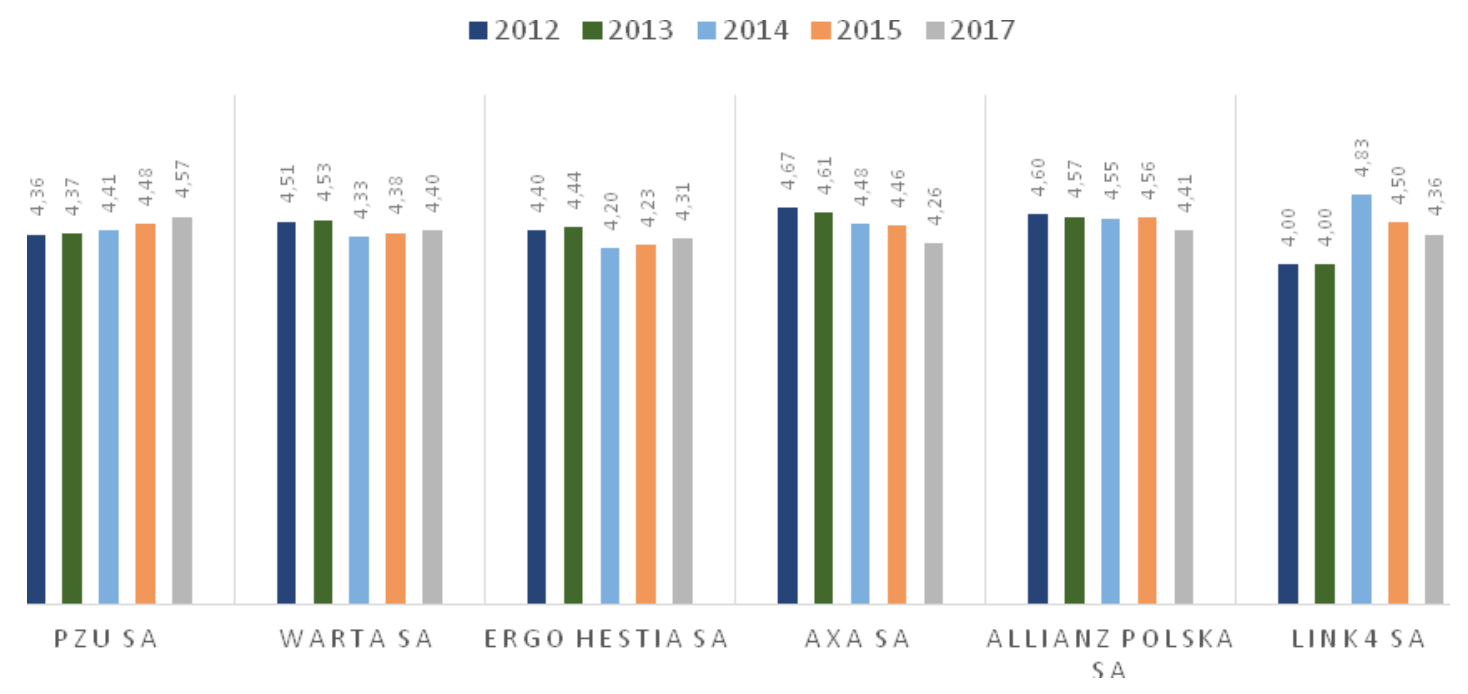

Fig. 6. Detailed indicators for image of insurance companies - modernity [TOP 6]

Source: Qualifact. Badania rynkowe i doradztwo, Raport: Finanse MSP 2012. Rynek ustug ubezpieczeniowych, Gdańsk 2012, s. 148; Qualifact. Badania rynkowe i doradztwo, Raport: Finanse MSP 2013. Rynek ushug ubezpieczeniowych, Gdańsk 2013, s. 155; Qualifact. Badania rynkowe i doradztwo, Raport: Finanse MSP 2014. Rynek usług ubezpieczeniowych, Gdańsk 2014, s. 168; Qualifact. Badania rynkowe i doradztwo, Raport: Finanse MSP 2015. Rynek usług ubezpieczeniowych, Gdańsk 2015, s. 153; Own research in 2017.

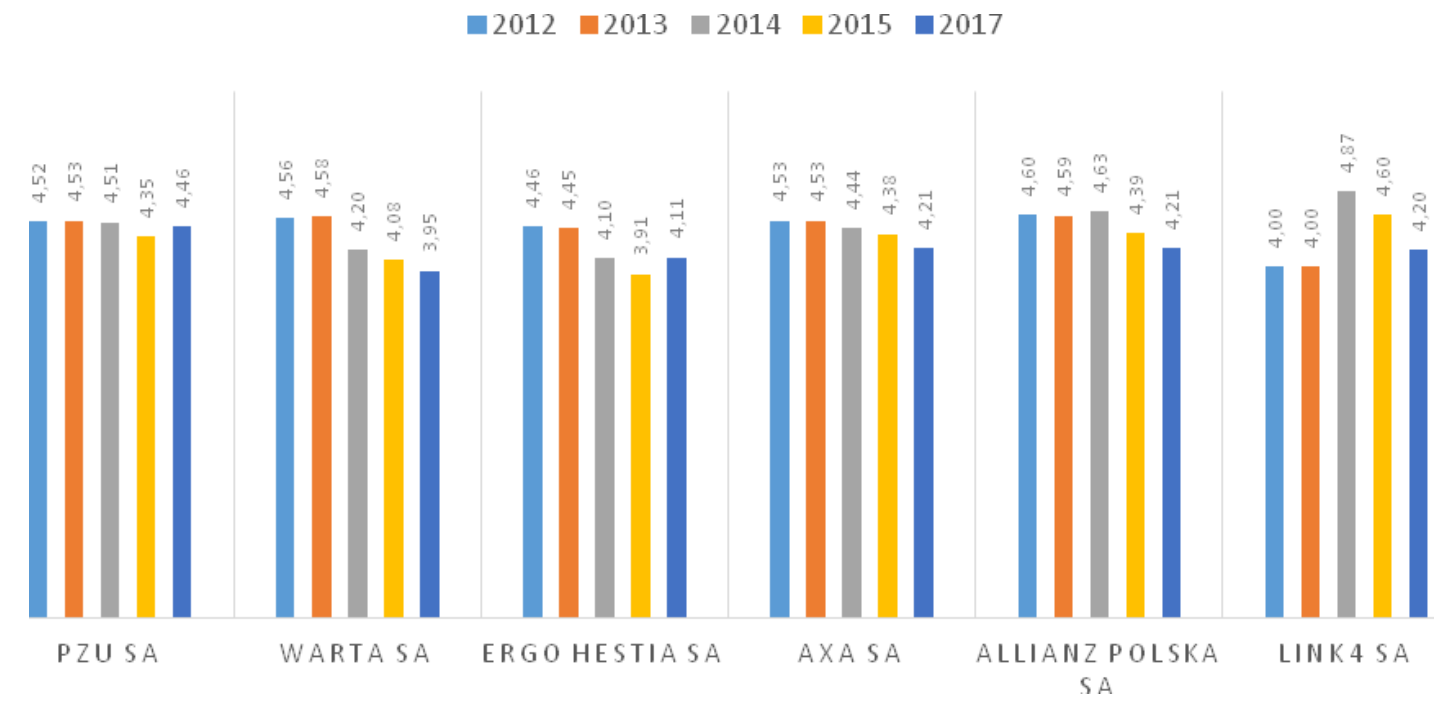

Fig. 7. Detailed indicators for image of insurance companies - dynamism [TOP 8]

Source: Qualifact. Badania rynkowe i doradztwo, Raport: Finanse MSP 2012. Rynek ustug ubezpieczeniowych, Gdańsk 2012, s. 148; Qualifact. Badania rynkowe i doradztwo, Raport: Finanse MSP 2013. Rynek ushug ubezpieczeniowych, Gdańsk 2013, s. 155; Qualifact. Badania rynkowe i doradztwo, Raport: Finanse MSP 2014. Rynek usług ubezpieczeniowych, Gdańsk 2014, s. 168; Qualifact. Badania rynkowe i doradztwo, Raport: Finanse MSP 2015. Rynek usług ubezpieczeniowych, Gdańsk 2015, s. 153; Own research in 2017. 


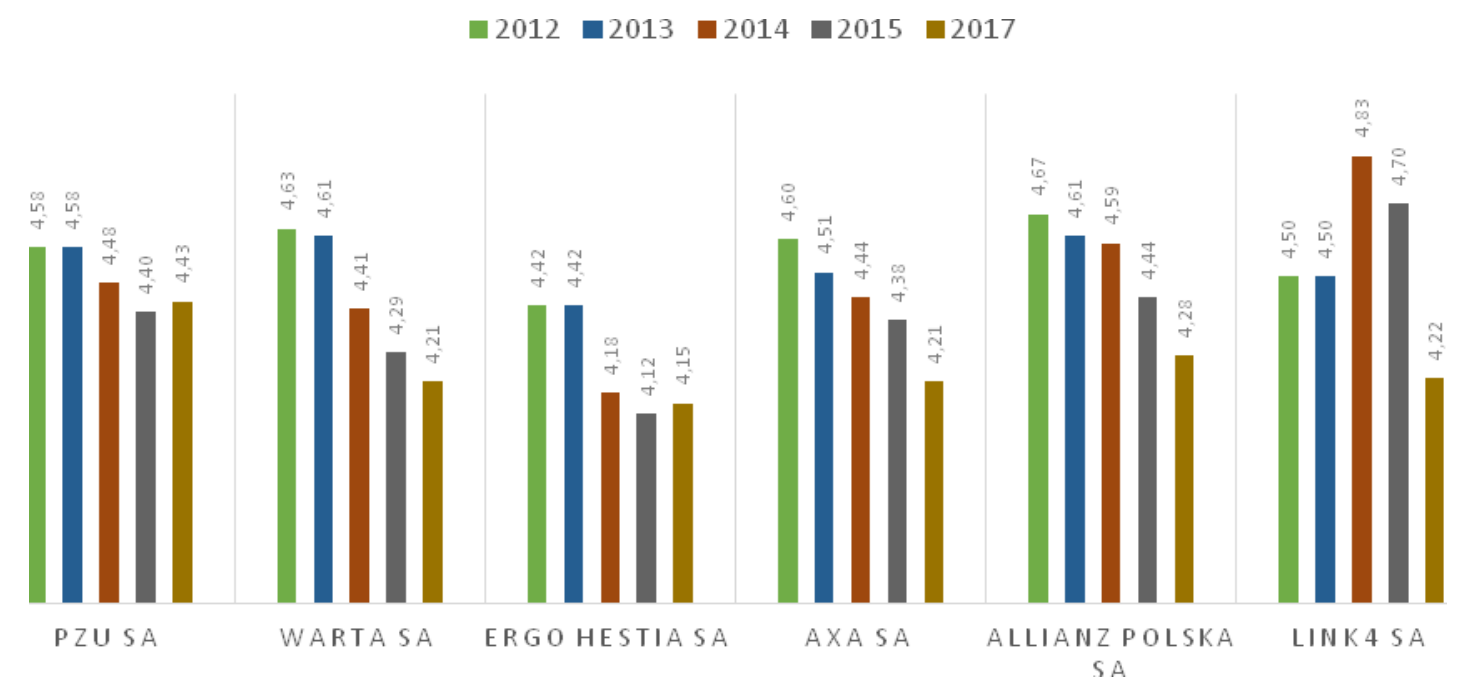

Fig. 8. Detailed indicators for image of insurance companies - professionalism [TOP 8]

Source: Qualifact. Badania rynkowe i doradztwo, Raport: Finanse MSP 2012. Rynek ustug ubezpieczeniowych, Gdańsk 2012, s. 148; Qualifact. Badania rynkowe i doradztwo, Raport: Finanse MSP 2013. Rynek ustug ubezpieczeniowych, Gdańsk 2013, s. 155; Qualifact. Badania rynkowe i doradztwo, Raport: Finanse MSP 2014. Rynek usług ubezpieczeniowych, Gdańsk 2014, s. 168; Qualifact. Badania rynkowe i doradztwo, Raport: Finanse MSP 2015. Rynek usług ubezpieczeniowych, Gdańsk 2015, s. 153; Own research in 2017.

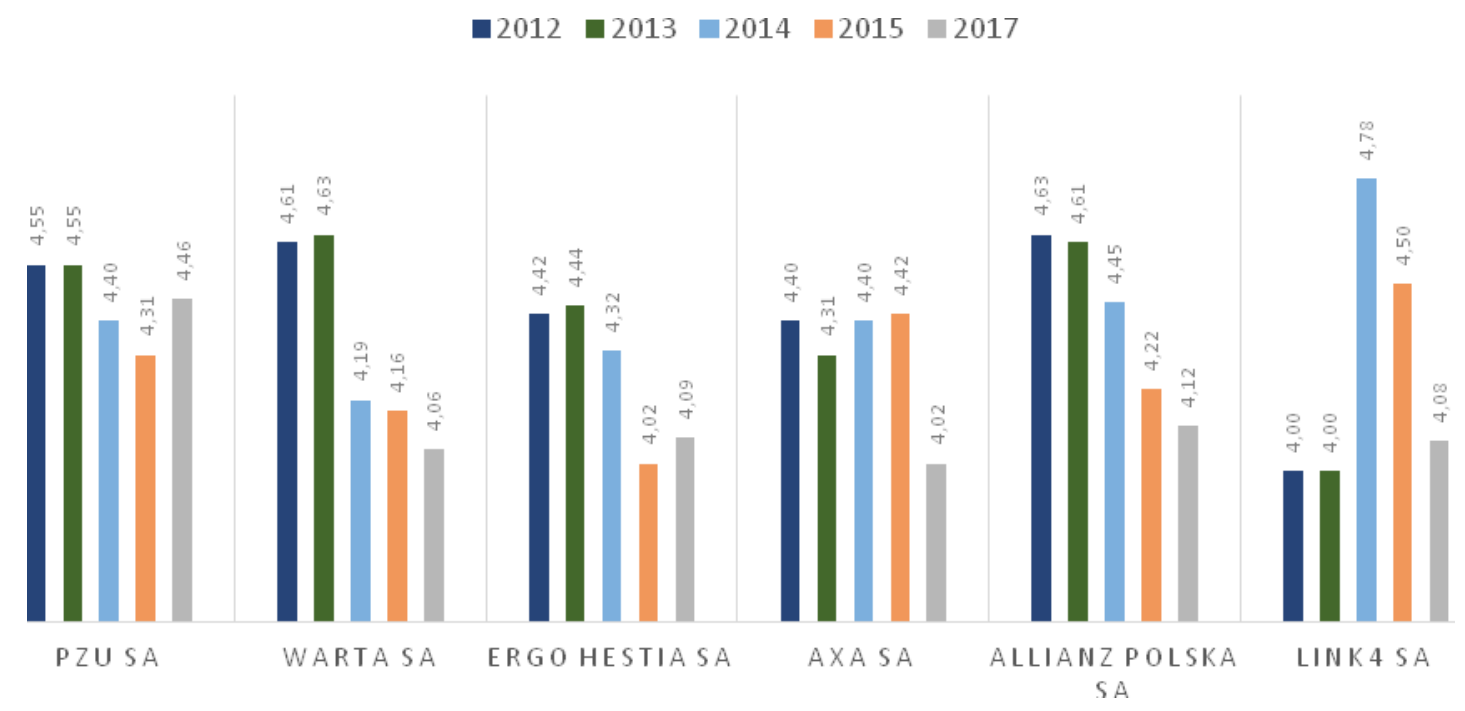

Fig. 9. Detailed indicators for image of insurance companies - range of offer [TOP 8]

Source: Qualifact. Badania rynkowe i doradztwo, Raport: Finanse MSP 2012. Rynek ustug ubezpieczeniowych, Gdańsk 2012, s. 148; Qualifact. Badania rynkowe i doradztwo, Raport: Finanse MSP 2013. Rynek ustug ubezpieczeniowych, Gdańsk 2013, s. 155; Qualifact. Badania rynkowe i doradztwo, Raport: Finanse MSP 2014. Rynek usług ubezpieczeniowych, Gdańsk 2014, s. 168; Qualifact. Badania rynkowe i doradztwo, Raport: Finanse MSP 2015. Rynek usług ubezpieczeniowych, Gdańsk 2015, s. 153; Own research in 2017. 


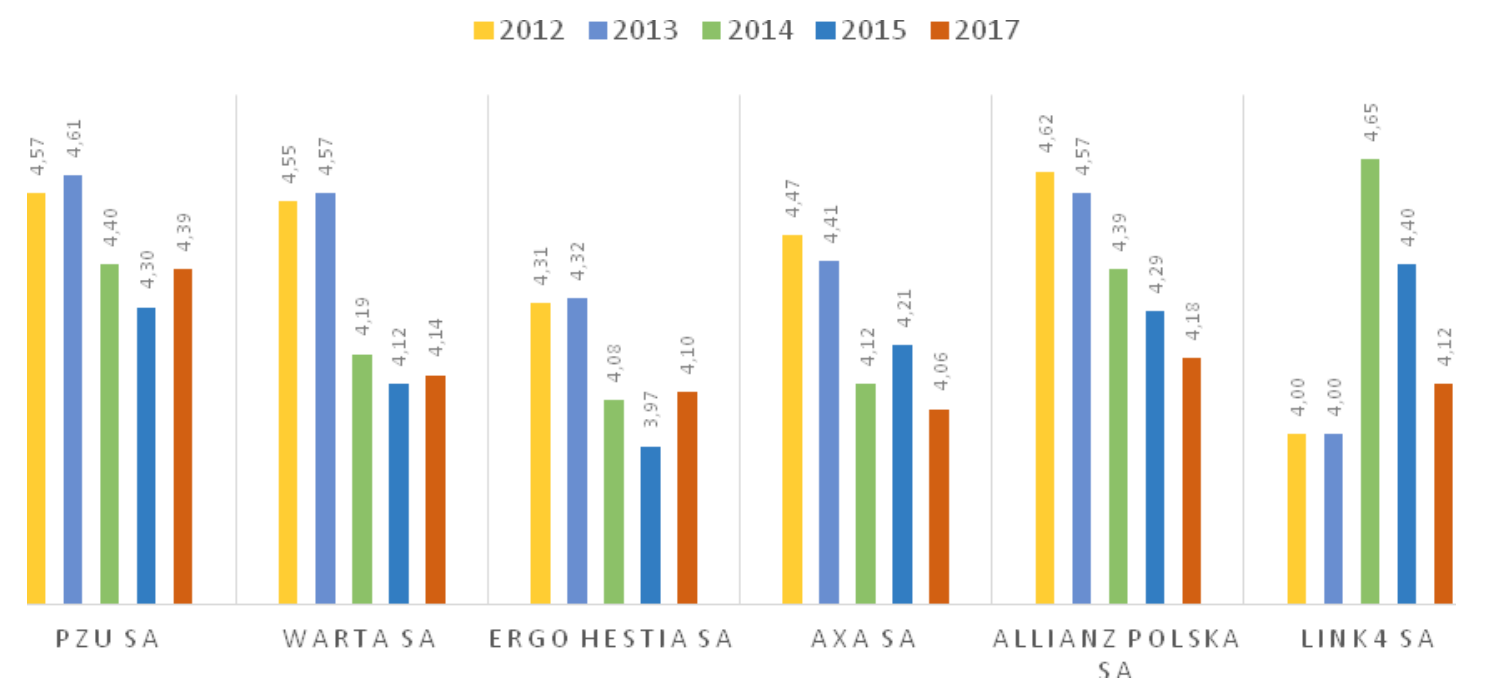

Fig. 10. Detailed indicators for image of insurance companies - prestige [TOP 8]

Source: Qualifact. Badania rynkowe i doradztwo, Raport: Finanse MSP 2012. Rynek ustug ubezpieczeniowych, Gdańsk 2012, s. 148; Qualifact. Badania rynkowe i doradztwo, Raport: Finanse MSP 2013. Rynek ustug ubezpieczeniowych, Gdańsk 2013, s. 155; Qualifact. Badania rynkowe i doradztwo, Raport: Finanse MSP 2014. Rynek usług ubezpieczeniowych, Gdańsk 2014, s. 168; Qualifact. Badania rynkowe i doradztwo, Raport: Finanse MSP 2015. Rynek usług ubezpieczeniowych, Gdańsk 2015, s. 153; Own research in 2017.

\section{Association tests}

The next question concerned the image of insurance companies in respondents' opinion. The respondents were requested to indicate, which insurance company most closely matched the following phrases (Fig.no. 11-14):

1. most secure insurance company;

2. the most modern insurance company;

3. the best company regarding services for enterprises;

4. the company offering the best service in terms of claims handling.

In all categories PZU SA was mentioned as a first best insurer. The second best company in each category was Warta SA, but it should be noticed and highlighted a significant distance in the achieved results comparing to the leader. 


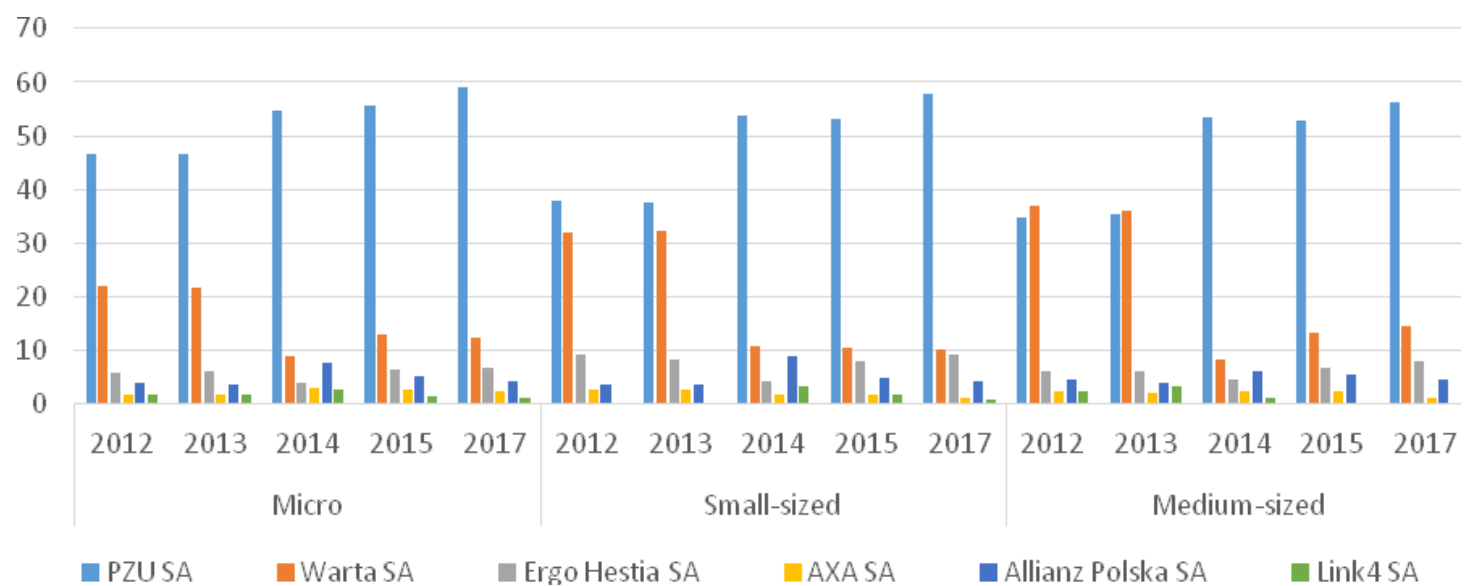

Fig. 11. Association tests - the safest insurance company in respondents' opinion [\%][TOP 6] Source: Qualifact. Badania rynkowe i doradztwo, Raport: Finanse MSP 2012. Rynek ustug ubezpieczeniowych, Gdańsk 2012, s. 152; Qualifact. Badania rynkowe i doradztwo, Raport: Finanse MSP 2013. Rynek ustug ubezpieczeniowych, Gdańsk 2013, s. 159; Qualifact. Badania rynkowe i doradztwo, Raport: Finanse MSP 2014. Rynek usług ubezpieczeniowych, Gdańsk 2014, s. 176; Qualifact. Badania rynkowe i doradztwo, Raport: Finanse MSP 2015. Rynek usług ubezpieczeniowych, Gdańsk 2015, s. 163; Own research in 2017.

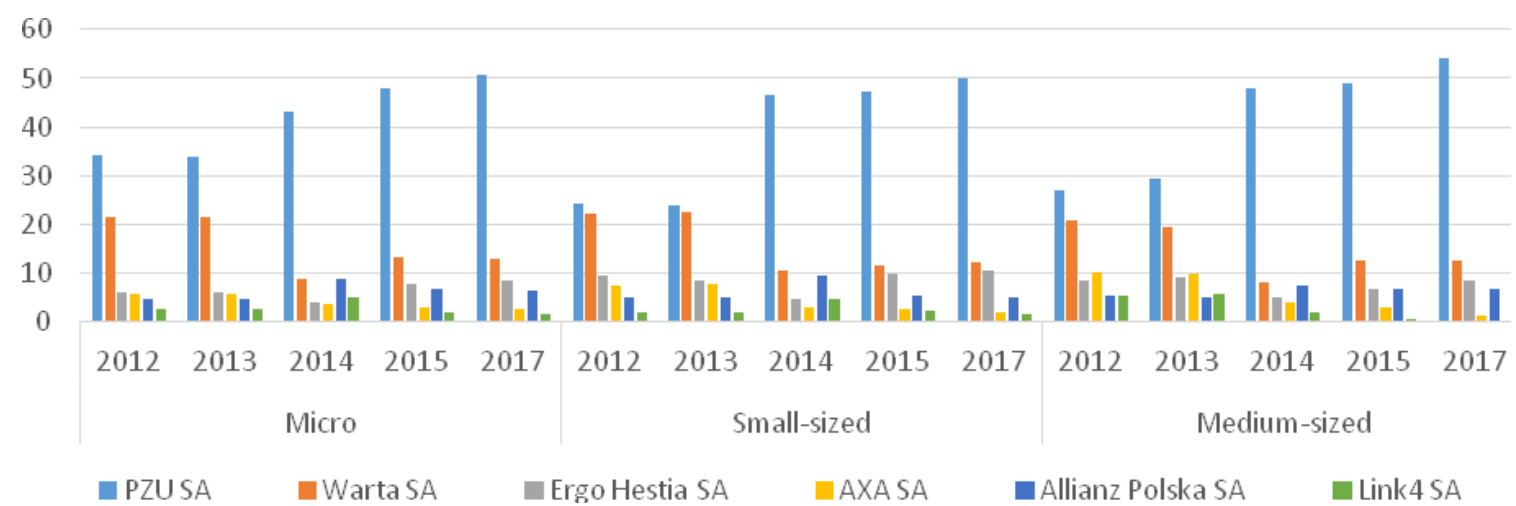

Fig. 12. Association tests - the most modern insurance company in respondents' opinion [\%][TOP 6]

Źródło: Qualifact. Badania rynkowe i doradztwo, Raport: Finanse MSP 2012. Rynek usług ubezpieczeniowych, Gdańsk 2012, s. 153; Qualifact. Badania rynkowe i doradztwo, Raport: Finanse MSP 2013. Rynek ustug ubezpieczeniowych, Gdańsk 2013, s. 160; Qualifact. Badania rynkowe i doradztwo, Raport: Finanse MSP 2014. Rynek usług ubezpieczeniowych, Gdańsk 2014, s. 177; Qualifact. Badania rynkowe i doradztwo, Raport: Finanse MSP 2015. Rynek usług ubezpieczeniowych, Gdańsk 2015, s. 164; Own research in 2017. 


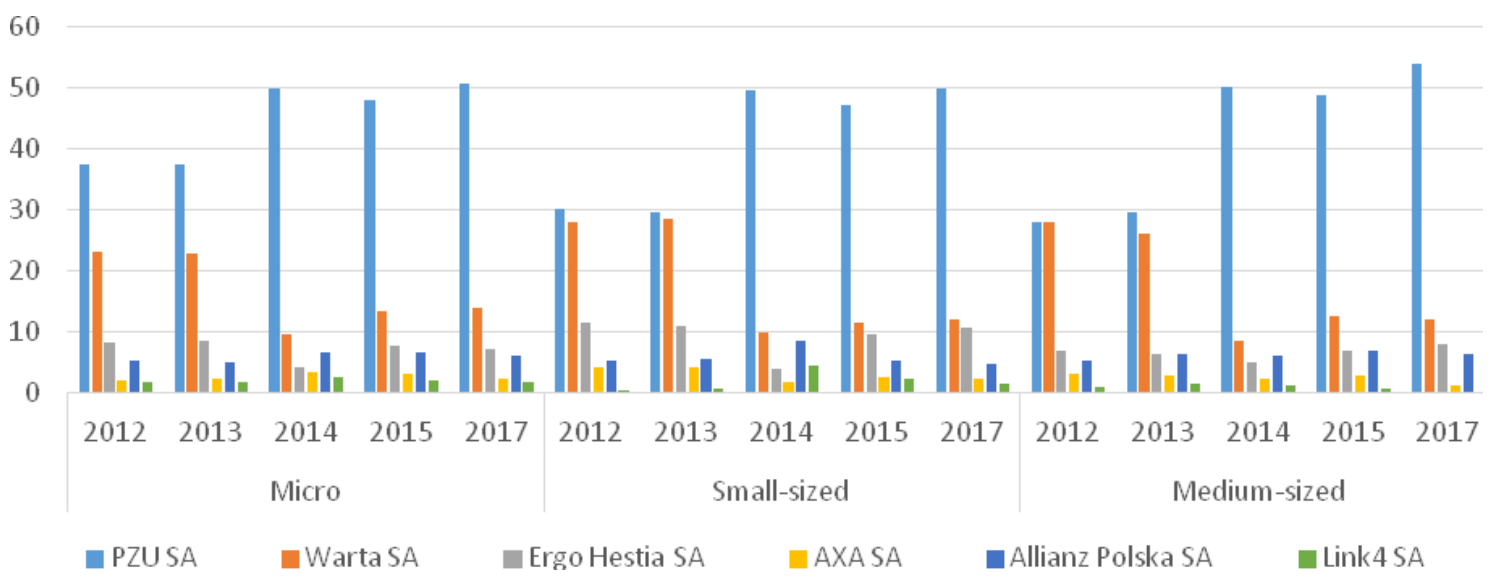

Fig. 13. Association tests - the best insurance company as regards services for enterprises [\%] [TOP 6]

Źródło: Qualifact. Badania rynkowe i doradztwo, Raport: Finanse MSP 2012. Rynek ustug ubezpieczeniowych, Gdańsk 2012, s. 153; Qualifact. Badania rynkowe i doradztwo, Raport: Finanse MSP 2013. Rynek ustug ubezpieczeniowych, Gdańsk 2013, s. 160; Qualifact. Badania rynkowe i doradztwo, Raport: Finanse MSP 2014. Rynek usług ubezpieczeniowych, Gdańsk 2014, s. 177; Qualifact. Badania rynkowe i doradztwo, Raport: Finanse MSP 2015. Rynek usług ubezpieczeniowych, Gdańsk 2015, s. 165; Own research in 2017.

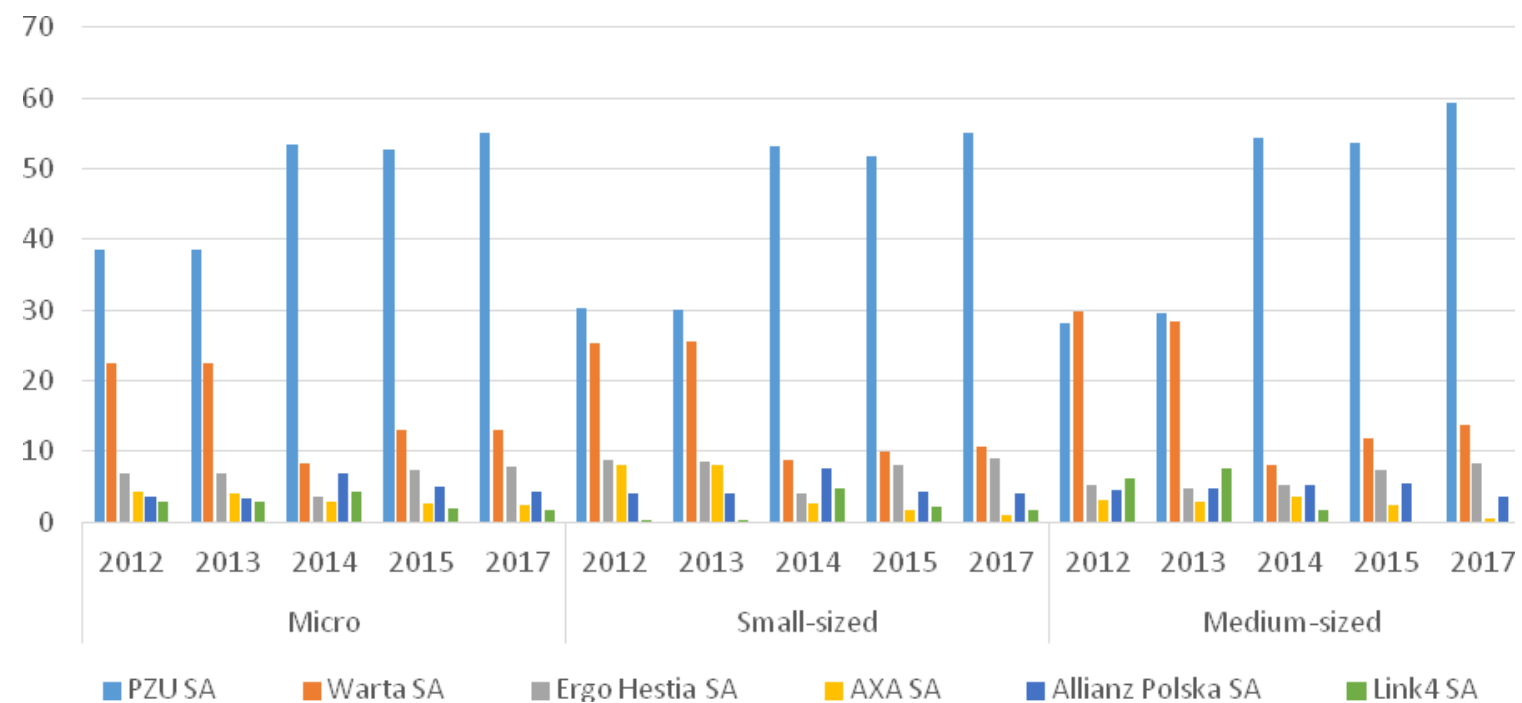

Fig. 14. Association tests - the best insurance company as regards offers the best service in terms of claims handling [\%][TOP 10]

Źródło: Qualifact. Badania rynkowe i doradztwo, Raport: Finanse MSP 2012. Rynek uslug ubezpieczeniowych, Gdańsk 2012, s. 154; Qualifact. Badania rynkowe i doradztwo, Raport: Finanse MSP 2013. Rynek ustug ubezpieczeniowych, Gdańsk 2013, s. 161; Qualifact. Badania rynkowe i doradztwo, Raport: Finanse MSP 2014. Rynek usług ubezpieczeniowych, Gdańsk 2014, s. 178; Qualifact. Badania rynkowe i doradztwo, Raport: Finanse MSP 2015. Rynek usług ubezpieczeniowych, Gdańsk 2015, s. 166; Own research in 2017.

\section{Conclusions}

The competitive advantage of the company from the point of view of its customers is the result of the combination of such elements as the price and quality of the product and the characteristics of the service and the image of the company. Differences in expectations, preferences and buyer's experience are the basis for subjective evaluations and perceptions. Thus, 
companies and brands can be seen as leaders in the same competitive advantage by different consumers.

The source of the unique offer on the market may be the product design and its features, production technology, service, or brand. In the market of consumer goods, however, the emotional differentiation, which is based on the creation of the brand and the positive associations associated with it, is more important. Branded products are perceived by consumers as unique and not substitutable by competing or substitutable products. The brand and its image provide the buyer with mainly emotional or symbolic benefits, which for the company is the source of the relationship with the customer.

The last significant element in building insurance brand image is the loyalty of customers. Loyalty to insurers depends on many factors, including, among other things, the level of brand awareness. Building long lasting relationships strengthens loyalty and at the same time weakens the motivation to change the insurer.

\section{Bibliography}

1. American Marketing Association, Dictionary, https://www.ama.org/resources/Pages/Dictionary.aspx?dLetter=B\&dLetter=B (15.10.2017).

2. Bednarz J., 2015. Marka jako źródło przewagi konkurencyjnej przedsiębiorstw przemysłu spożywczego. [w:] Konkurencyjność polskich producentów żywności i jej determinanty (1), red. I. Szczepaniak, seria „Monografie Programu Wieloletniego 2015-2019”, Nr. 11, Warszawa, IERiGŻ-PIB.

3. Bednarz J., 2007. Zarządzanie marką produktów przez współczesne przedsiębiorstwa. [w:] Dylematy i perspektywy rozwoju współczesnych przedsiębiorstw, red. J. Fryca i D. Wach, Gdańsk, Polskie Towarzystwo Ekonomiczne.

4. Cohen H., 30 Branding Definitions, http://heidicohen.com/30-branding-definitions/ (15.10.2017).

5. Dębski M., 2009. Kreowanie silnej marki, Warszawa, PWE.

6. Kall J., 2006. Istota marki. ,Integracja Europejska”, No. 3.

7. Kall J., Kłeczek R., Sagan A., 2013. Zarzadzanie marką, Warszawa, Wolters Kluwer, pp. 15-17.

8. Kompendium wiedzy o marketingu. Red. B. Pilarczyk, H. Mruk, 2006. Warszawa, PWN.

9. Kotler P., 2001. Marketing. Podręcznik europejski. Warszawa, PWE.

10. Kotler P., 2012. Marketing, Poznań, REBIS.

11. Oniszczuk-Jastrząbek A., 2007. Marketing w kształtowaniu jakości produktu. [w:] Przedsiębiorstwo - zasady działania, funkcjonowanie, rozwój. Red. J. Żurek, Gdańsk, Fundacja Rozwoju Uniwersytetu Gdańskiego.

12. Oniszczuk-Jastrząbek A., Czuba T., 2017. Jakość obsługi klienta w sektorze małych i średnich przedsiębiorstw na przykładzie usług ubezpieczeniowych. [w:] "Marketing i Zarządzanie", No.5.

13. Staszyńska K. M., 2013. Marka Konsument Badacz. Warszawa, Wolters Kluwer.

14. Szymczak M. (pod red.), Słownik języka polskiego. 1981. Warszawa, PWN.

15. Urbanek G., Zarządzanie marką, 2002. Warszawa, PWE.

16. Qualifact. Market Research and Analysis (2012, 2013, 2014, 2015). Report: Finanse MSP 2012, 2013, 2014, 2015. Rynek usług ubezpieczeniowych. Gdańsk. 